\title{
The Marchoux Institute
}

\author{
P SAINT ANDRE \\ Director, Institute Marchoux, BP 251, Bamako, Mali, \\ Africa
}

Received for publication 12 March 1979

\begin{abstract}
Summary-An account is given of the origin and development of the Marchoux Institute in Bamako and of its present-day activities as a centre of research in dermatology, leprology, tropical epidemiology and as a collaborating centre with WHO. Thanks to the collective efforts of the 8 member states of OCCGE (Organisation de Coordination et de Coopération pour la Lutte Contre les Grandes Endémies), together with financial assistance from ILEP (The International Federation of Anti-Leprosy Associations), the Institute has intensified its activities in the fields of research, training of personnel, and the organization of control work in the field.
\end{abstract}

\section{Historical account}

As far back as the early years of this century, the Health Authorities of the French-speaking countries of West Africa were aware of the dimensions of the leprosy endemic they were facing. The administrative centralization characteristics of France proved to be adaptable to conditions in West Africa providing, as it did, for the establishment of a plan of campaign for the control of the major endemic diseases. The overseas medical corps, consisting in the most part of doctors from the Navy Health Department in Bordeaux who had undergone special training in tropical medicine, formed the core of the various health campaigns in these African countries.

After the successful control of trypanosomiasis (due to the strategy devised and exemplified by Jamot), of yellow fever (eliminated by the Dakar vaccine developed by Laigret), and of smallpox, there remained to be tackled the scourge of leprosy. When no medication better than chaulmoogra-oil was available, it was evidently necessary for research in leprosy to be prosecuted, and for auxiliary staff to be trained to secure data on the health situation and to carry out a campaign for the control of transmissible diseases.

Thus it was that the Marchoux Institute came into being, bearing the name 
of a distinguished French scientist who had done important work on leprosy. Founded in the year 1934, the Institute has trained successive generations of medical auxiliaries who were available when the sulphone drugs appeared on the scene in the years following the Second World War. Several Directors have made their mark - Tisseuil and Baudiment before the war; Laviron from 1940-1957, Languillon from 1957-1971, and then Saint-André.

Pharmacologists attached to the Institute discovered local plants that provided a source for chaulmoogra-oil and a full-blown factory produced enough oil to supply all the French territories. Laviron and Jardin made a formulation of a long-acting suspension ( 15 days) of sulphone in chaulmoogra-oil. Languillon conducted many drug trials, and showed the efficacy of the long-acting sulphonamides. Bourrel, and after him, Giraudeau, pioneered the surgery of nerves and reconstructive procedure. Carayon, from Dakar, took a lively interest in this work and cooperated with them. Sansarricq instituted activities in epidemiology.

The Marchoux Institute has thus benefited from a very capable staff ever since its formulation despite the ups and downs due to the Second World War and various episodes of civil disturbance and war in Africa itself.

\section{The present situation}

In 1960, the decision of France to grant independence to African colonies led to the break-up of the older divisions (French Oriental and French Equatorial Africa) into various autonomous States and it was feared that the health gains might be placed in jeopardy.

Good sense eventually triumphed; thanks to the new leaders and especially to the personal influence of Doctor-General Richet, a kind of 'common market' in health matters came into being in the newly independent countries of French West Africa. Thus it was that OCCGE was formed - the Organization for Cooperation and Coordination in the Control of Endemic Diseases. This inter-State organization, of which France is a member, has its headquarters in Bobo-Dioulasso in Upper Volta. Here the Muraz Institute is concerned with research in bacteriology, parasitology and epidemiology, and trains laboratory staff. The doctors are joined by French research entomologists from the Overseas Scientific and Technical Bureau. In addition, there is at Bouake (in the Ivory Coast) a centre specializing in onchocerciasis.

In Bamako, there are two Institutes - the Marchoux Institute for leprosy, and the Institute for Tropical Ophthalmology, and in Dakar there is an Institute engaged in nutritional research.

The doctors and the staff of these institutes are mostly Army doctors, seconded from and paid by the French Overseas Cooperative Service, and placed at the disposal of the Organization. The same applies to the various 
research workers. Africans are in the process of taking over at the present time.

The budgets of these Institutes, under the control of a Secretary-General, are supplied by the Member-States. Besides their research programmes in the various fields, the workers are instructed each year by the Member-States to carry out a programme of practical intervention, such as a newly-discovered outbreak of tryphanosomiasis, or some epidemic. Teams composed of variously qualified experts act as task forces, bringing help even to less accessible areas where they treat various diseases in a combined effort. staff.

The Institutes exercise a most important role in the training of auxiliary

\section{The Marchoux Institute}

The Institute, being in a central geographical situation, acts as a focus for the various Member-States: Benin, Ivory-Coast, Upper-Volta, Mali, Mauritania, Niger, Senegal, Togo (Guinea, a former member, is no longer interested).

\section{A - BUILDINGS}

Four large two-storey buildings, two of which house the staff (nurses, visitors' rooms for doctors), and the other two are for the administrative services, the Director's office, classrooms, consulting rooms, epidemiology service, and the bacteriological and parasitological laboratories.

A fifth large one-storey building houses the chemical and immunological laboratories, and the ophthalmological consulting room with that of the dermatologist adjoining. Other buildings include:

A surgical block comprising two operating theatres and a recovery room, three wards with 110 beds, a building for the pharmacy and tailor, a building for radiology, 2 buildings used as out-patient dispensaries, treating 1,500 leprosy patients, 82 small houses for leprosy patients participating in controlled trials (most of these patients have lepromatous leprosy; residence guarantees regular treatment), various storerooms, and kitchens, four villas and five apartments for doctors and African (male) nurses, lodgings for probationers, two schools; a chapel; a mosque.

All these buildings have suffered in the past because the purchasing power of an unchanged budget did not permit proper maintenance. Recent financial help from ILEP (Follereau Foundation) will permit renovation.

\section{B - EQUIPMENT}

Surgical instruments and laboratory equipment have been recently renewed, thanks to a grant from ILEP. 
C - STAFF

Reduced in 1971 to two doctors (the Director and a surgeon), it now consists of five:

The Director, a dermatologist, a Professor on special assignment, an assistant dermatologist; an epidemiologist, a graduate of the National School of Public Health, Rennes; a hospital surgeon; a pharmaceutical biochemist, and a (French) female laboratory assistant.

All these members of staff belong to the French Cooperation Service; the four doctors are Navy doctors seconded to this service. The medical staff is assisted by four nurses (of whom three are nuns), from Canada, France and the Netherlands. Of the five indigenous qualified and highly competent African nurses, four are from Mali and one from Benin; one X-ray technician and three laboratory staff are from Mali. The ophthalmologists from the Institute cooperate with the staff of the Institute Marchoux and visit the clinics regularly.

\section{D - ACTIVITIES}

\section{Training of staff}

The whole basis of the admission of patients to hospital and the training of staff, is clinical consultation.

A dermatologist - and the first such specialist to work in the Institute since its foundation - the present Director has made a point of reintegrating leprosy into dermatology. The advantages are obvious: a better knowledge of differential diagnosis, especially of early forms of leprosy which leads to better training of probationary staff and hence more accurate case finding. It is evidently of the greatest importance to diagnose the disease at its earliest stages, when the signs are still equivocal. Furthermore, case finding is made easier by reason of the fact that patients come complaining of some skin condition - not for leprosy - that may be camouflaged by any other dermatosis. The patient does not start with the idea that he might have leprosy simply because he is going to the Marchoux Institute. This system has led to a fourfold increase in the discovery of early cases of leprosy, and its success has made the appointment of a second dermatologist necessary.

The probationer-auxiliaries gain a good knowledge of diagnostic dermatology. They can be useful in a wider field, as for example in onchocerciasis; trained in the search for $M$. leprae: they can also examine sputum for $M$. tuberculosis. Thus, this category of auxiliary is more profitable elsewhere.

\section{Categories of trained staff}

Two kinds of practical instruction are offered to the students coming from the French-speaking countries: 
(a) Leprosy controllers. These are auxiliaries who have had a general training and several years of practical experience, who come to the Institute to gain knowledge of leprology. Their course is of three months' duration. The instruction is essentially practical:

outpatient clinics in dermatology

case presentation

practical laboratory work.

The theoretical instruction is as concise as possible and always illustrated by clinical demonstrations.

These probationers are integrated into the life of the hospital, and take their turn in the clinics, wards, dispensary and laboratory. Besides, they are trained in view of their epidemiological bias, by a specialist. Their function will be to control the medical case provided by auxiliaries in a given district, to keep the record cards up-to-date by means of an annual examination, and to organize case-finding campaigns.

(b) Leprosy specialists. These are recruited in small numbers from the best of the leprosy controllers who have been on the job for some years. They follow a one-year course, and share fully in the work of the Institute and hospital during this year. Their function is to supervise the work of the leprosy controllers and to offer advice to the doctors, who may not be very familiar with the leprosy campaign.

The Director, a professor at the Medical School, Mali, teaches dermatology to students in their fifth year. The students also follow practical courses during their attendance at these lectures.

As will be seen, the training of staff - the traditional role of the Institute Marchoux - has greatly increased during the past few years, and will increase still more in the future.

\section{Research}

More recently, research activities have concentrated on chemotherapeutic trials in cooperation with WHO, long-acting DADDS (Hansolar), clofazimine, and drug combinations (rifampicin and other drugs); and especially on the stimulation of cell-mediated immunity by different products, such as BCG vaccine, Neisseria Perflava, microbial lysates, and levamisole - all in previously untreated patients suffering from lepromatous leprosy.

Initially used alone with success, these various products have been given in association with different drugs, with good results. These trials have been monitored by the use of the macrophage migration inhibition test. Other components are on trial.

The study of ENL has been pursued along clinical, anatomo-pathological and therapeutic lines; the remarkable activity of chloramphenicol has been noted. Important observations on the positive and differential diagnosis of 
leprosy have been made. A teaching film has been produced.

A study of eye lesions has been made and the existence of retinal lesions has been noted. Attention has been directed to inflammatory episodes occurring in the course of tuberculoid leprosy (BT); many patients have been followed for several years along clinical and immunological lines, and immunological reversal reactions associated with unpredictable and severe nerve damage have been demonstrated.

Such patients have been treated by means of rifampicin and corticosteroids together, and then with long-acting sulphonamides and clofazimine, and also by specific desensitization, using progressively increasing doses of lepromin. This method has unquestionably improved the skin and nerve lesions, a combination of these two lines of treatment having proved the most beneficial.

\section{Epidemiology}

In the different French-speaking countries, pilot surveys of the population at risk have permitted a precise evaluation of the dimension of the leprosy endemic: these suggest a 25-30\% proportion of the official figures. Actually, the recommendation of the WHO regarding 'discharge from treatment' and 'cure' of tuberculoid forms had not been adhered to. It is thus apparent that the 20-year-old leprosy campaign has been a real success.

On behalf of the WHO, a pilot area 90 miles away from Bamako, has been studied for three years. A count of patients under treatment will be made after a census of the whole population, in order to provide a basis for various field enquiries in the future.

Finally the Institute has been active in the field of tropical dermatology (onchocerciasis, trypanosomiasis), and appropriate publications have appeared in the French medical literature.

\section{Reconstructive surgery}

This has greatly benefited from the work of Dr Giraudeau who has elaborated some original techniques and simplified certain classical procedures.

\section{Conclusion}

Thanks to the collective efforts of the Member-States, thanks also to the financial help of ILEP, the Marchoux Institute has increased its activities during the past few years in the important fields of research and training of staff. It has resumed its field activities in the evaluation and organization of anti-leprosy campaigns among the eight Member-States of the OCCGE. 


\section{Acknowledgement}

I wish to record my sincere thanks to Dr S G Browne, the Leprosy Study Centre, 57a Wimpole Street, London, for his expert translation of the original.

Table 1. Epidemiologie de la lepre en Afrique de l'Ouest Francophone. Commencée sur une grande échelle en 1955, par la mise en place des circuits de masse antihanséniens, la campagne de lutte contre la Maladie de Hansen (détection et traitement) dans les pays de l'Afrique de l'Ouest Francophone s'est intensifiee dupuis lors. Les chiffres rapportés dans le tableau I correspondent à l'évolution entre 1955 et 1970.

\begin{tabular}{lcccc}
\hline & 1955 & 1960 & 1965 & $1970 \dagger$ \\
\hline Lépreux recensés & 250,257 & 378,218 & 525,931 & 465,494 \\
Lépreux traités & 127,077 & 228,870 & 226,217 & 223,221 \\
Lépreux traités & & & & \\
$\quad$ régulièrement & & 106,053 & 190,576 & 157,076 \\
I.S.T. & & 108,803 & 106,705 \\
\hline
\end{tabular}

I.S.T. = Inactivés sans traitement.

$\dagger \quad=$ Sans le Togo et la Guinnée.

Table 2. La lepre dans les etats de l'OCCGE. Evolution de la situation épidémiologique dans l'ensemble des Etats de 1971 à 1976

\begin{tabular}{|c|c|c|c|c|c|c|c|}
\hline ANNEE & $\begin{array}{l}\text { Population } \\
\text { estimée }\end{array}$ & $\begin{array}{l}\text { Lépreux } \\
\text { recensés }\end{array}$ & $\begin{array}{c}\text { Prévalence } \\
\text { pour } \\
1000\end{array}$ & $\begin{array}{c}\text { Nouveaux } \\
\text { lépreux } \\
\text { (dépistés } \\
\text { dans } \\
\text { l'année) }\end{array}$ & $\begin{array}{c}\text { Incidence } \\
\text { pour } \\
1000\end{array}$ & Inactivés & $\begin{array}{l}\text { Inactivés } \\
\text { Total } \\
\text { lépreux } \\
\text { recensés } \\
(\%)\end{array}$ \\
\hline 1971 & $27,936,000$ & 471,870 & 16.9 & 15,578 & 0.6 & 174,640 & 41.9 \\
\hline 1972 & $28,720,000$ & 468,485 & 16.3 & 16,056 & 0.6 & 173,147 & 41.4 \\
\hline 1973 & $29,314,000$ & 456,223 & 15.6 & 14,265 & 0.5 & 171,740 & 42.3 \\
\hline 1974 & $29,856,000$ & 433,742 & 14.5 & 14,663 & 0.5 & 166,628 & 43.1 \\
\hline 1975 & $30,651,000$ & 405,657 & 13.2 & 14,267 & 0.5 & 150,917 & 37.5 \\
\hline 1976 & $28,776,000^{\dagger}$ & 339,203 & 12 & 11,844 & 0.4 & 144,679 & 42.6 \\
\hline
\end{tabular}

†Population en 1976 : sauf Bénin et Mauritanie 
Table 3. La Lepre dans les Etats de l'OCCGE. Situation épidémiologique en 1976: vue détaillée de la situation dans les differents états membres de l'OCCGE (Organisation de Coordination et de Coopération pour la Lutte Centre les Grandes Endémies).

\begin{tabular}{|c|c|c|c|c|c|c|c|}
\hline Etats & $\begin{array}{l}\text { Population } \\
\text { estimée }\end{array}$ & $\begin{array}{l}\text { Lépreux } \\
\text { recensés }\end{array}$ & $\begin{array}{c}\text { Prévalence } \\
\text { pour } \\
1000\end{array}$ & $\begin{array}{c}\text { Nouveaux } \\
\text { lépreux } \\
\text { (dépistés } \\
\text { dans } \\
\text { l'année) }\end{array}$ & $\begin{array}{c}\text { Incidence } \\
\text { pour } \\
1000\end{array}$ & $\begin{array}{c}\text { Total } \\
\text { inactivés }\end{array}$ & $\begin{array}{c}\text { Inactives } \\
\text { Total } \\
\text { lépreux } \\
\text { recensés } \\
(\%)\end{array}$ \\
\hline Bénin & $3,210,000$ & $-\dagger$ & & - & - & - & - \\
\hline Cote D'Ivoire & $5,008,000$ & 94,758 & 18.9 & 3,050 & 0.6 & 44,879 & 47.4 \\
\hline Haute-Volta & $6,166,000$ & 82,909 & 13.4 & 2,215 & 0.4 & 50,912 & 61.4 \\
\hline Mali & $5,869,000$ & 101,746 & 17.4 & 2,845 & 0.5 & 29,717 & 29.2 \\
\hline Mauritainie & - & - & - & - & - & - & - \\
\hline Niger & $4,725,000$ & 21,495 & 4.5 & 1,108 & 0.2 & 2,690 & 12.5 \\
\hline Senegal & $4,185,000$ & 21,764 & 5.2 & 1,461 & 0.3 & 4,460 & 20.5 \\
\hline Toga & $2,333,000$ & 16,531 & 7.1 & 1,165 & 0.5 & 12,021 & 72.5 \\
\hline Total/OCCGE & $28,276,000+$ & 339,203 & 12 & 11,844 & 0.4 & 144,679 & 42.6 \\
\hline
\end{tabular}

† Aucuneinformation en 1976

¥Population en 1976' sauf Bénin et Mauritanie

Prévalence pour $1000=\frac{\text { Lépreux en compte } \times 1000}{\text { Population recensée }}$

Incidence pour $1000=\frac{\text { Nouveaux lépreux } \times 1000}{\text { Population recensée }}$ 